\title{
THE DESIRED PROFESSIONAL COMPETENCIES IN THE HOSPITALITY INDUSTRY IN NUEVA VIZCAYA
}

\author{
Evangeline H. Castro, PhD \\ Assistant Professor III, Nueva Vizcaya State University, Bambang, Nueva Vizcaya, Philippines 3702
}

Article DOI: https://doi.org/10.36713/epra8763

DOI No: 10.36713/epra8763

\begin{abstract}
The hospitality industry covers an extensive range of occupations, including those related to food service and lodging which require continuous innovations and improvement. This study determined the level of desired professional competencies in the hospitality industry in Nueva Vizcaya. Descriptive correlational method was employed to discover the relationships that exist between variables and to elicit data from hospitality professionals and educators from business establishments accredited by the Department of Tourism and higher education institutions in Nueva Vizcaya who participated in this study. A modified questionnaire, frequency counts and percentage, mean and correlational procedure were used to analyze and interpret data. Findings of the study showed that the desired professional competencies of respondents along personal effectiveness competencies, workplace competencies, and specific industry-sector competencies particularly on Lodging Management and Food and Beverage Management were very high. Likewise, respondent's intellectual competencies, industry wide competencies, and specific industry sector competencies particularly along Beverage Service; Culinary Arts; Front Office Procedure; Destination Marketing and Management; Tour Operations and Travel Management; Recreation, Amusement and Attractions; and Meetings, Events, and Exhibitions Management were high. It was found also that age and civil status significantly correlates with specific industry sector competencies particularly Beverage Service. However, the most crucial scenario to address is how to increase the understanding of certain managerial competencies and leadership styles to converge industry needs more accurately, to be more effective and successful managers or entrepreneurs. In this context, the researcher opted to propose for the enhancement of the curriculum of the Bachelor of Science in Hotel and Restaurant Management program to hospitality educators in Nueva Vizcaya.
\end{abstract}

KEYWORDS: Competencies, Professional Competencies, Hospitality Industry

\section{INTRODUCTION}

If there is one industry that have touched our lives by some means or other, it is no other than the hospitality industry, no matter where we are and what industry we belong. Although the hospitality industry is constantly changing in all aspects due to the changing demands, and needs of consumers including external forces like economy, politics, culture, and the like, the industry continues to influence and affect peoples' lives from all corners of the world. Conforming to the disclosure of World Travel and Tourism Council (WTTC) (2014) on contribution to employment, travel and tourism generated 105,408,000 jobs directly in 2014 (3.6\% of total employment) and this is forecast to grow by $2.0 \%$ in 2015 . Thus, this also includes job by hotels, travels representatives, airlines and other means of transportation services, restaurant or food and beverage services as well as convenience and recreation industries sustain by tourists. Aside from this, the tourism and hospitality employers anticipate the graduates to possess transferable standard competencies particularly in the areas of leadership, communication, strategic thinking and decision-making related to customer relations, computer skills, marketing media, security and safety.

Essential competencies in the hospitality industry have been recognized globally as well as recommended to provide organizational focus as building blocks for human resource systems and as a method for certifying attainment of job skills. The level of skills, abilities, values and knowledge have by workers will basically determine their professional competence. Thus, hospitality education produces graduates who are equipped with necessary competencies to guarantee excellent and quality of services (Valachis, 2003).

In a similar manner, the study by Tesone, et al. (2010) found out that both managers and workers reported the same rankings of responses concerning the perceived importance of attributes that constitute both knowledge, and skills and competencies for entry-level lodging and food service workers. Side by side, Shariff, et al. (2014) affirmed that the industry perceives the ability to work in teamwork as a vital competency even when it stands as a second competency the industry expected the graduates to possess. Wilks, et al. (2011) in their collaborative research likewise concluded that priority should be given to soft competencies, that educating students to manage hospitality units represents a formidable challenge. Moreover, students need to acquire knowledge of economics, management, and other sciences in addition to vocational subjects aside from the need of competencies to perform well. Furthermore, the study concluded that hospitality 
management is increasingly becoming an academic subject on its own right.

In the Philippine setting, a discrepancy in terms of competence in the job-worker matching was revealed by Peren (2012) in her published thesis on Reengineering of Bachelor of Science in Hotel and Restaurant Management Curriculum to harmonize with K-12 program as basis for curriculum development at HRM. Furthermore, graduates were noted to be undercompetent because their competence levels were below those required in their jobs. Significant gaps intervening competence and the required competencies entailed to perform their jobs at the hotel were recognized specifically, on the following employability characteristics and skills: initiative, team work, adaptability/flexibility, customer relations, dependability, written communication, responsibility, verbal communication, accounting and financial management, computer usage, and sales and promotion.

Zabala, et al. (2014) in their study on Students' Evaluation of the BSHRM Program: A Basis for Future Curriculum Revision at Mindanao State University revealed that the BSHRM program as evaluated by the students has to be revised in terms of the time allotted to each course if it is sufficient, excessive or inadequate. Also, tools, equipment, and textbooks that are relevant in the field should be provided for the program instruction in order for the students to enhance properly their knowledge and develop their abilities, talents, and skills subject to the actual work. To such a degree, balancing the different competencies between theory and practice is required from the hospitality management education and the hospitality industry.

Currently, the Hospitality and Tourism program in the province of Nueva Vizcaya is being offered by public and private colleges and universities including various technical or vocational schools offering the program in the diploma level. The Hospitality and Tourism Program must level up in order to successfully respond to the increasing challenges of the province, which has a lot of historical and natural attractions, religious and man-made tourists' attractions, festivals and special interest tours. Nueva Vizcaya stands strong and is proudly transforming into a fast-developing province with its fifteen municipalities. Each of these sites has its own promising land features, unique products, tourism attractions and services.

\section{OBJECTIVES}

The aim of this study is to determine the required desired professional competencies perceived as priority in the hospitality industry within the province of Nueva Vizcaya as bases for enhancing the BSHRM curriculum to the different hospitality educators that will ensure graduates to possess the desired skills set for the job market and also to enable the graduates to manage the rapidly changing demands in today's hospitality industry, addressing increased competition, changing consumer attitudes, trends and employer demands.

\section{METHODOLOGY}

The descriptive correlation method was utilized in the study to relate the desired professional competencies as perceived by industry professionals or practitioners and educators on the present and existing conditions of hospitality industries in Nueva Vizcaya. The participants were the hospitality professionals and educators from the fifteen municipalities of the province of Nueva Vizcaya particularly in areas where there are Hospitality and Tourism Industries accredited by the Department of Tourism-Region 02 were included. The study made use of a modified questionnaire from the Employment and Training Administration (ETA). The instrument includes two major competencies: the foundational competencies and the industry-specific competencies. Foremost of the instrument is the profile of respondents and the second part is the level of desired professional competencies along personal effectiveness, intellectual, workplace, industry-wide, and specific industry sector competencies. Data were processed using the frequency counts and percentage, weighted mean and correlational procedure.

\section{RESULTS AND DISCUSSION}

Of the 103 hospitality professionals and educators, forty-six percent are within the age bracket of 20-29, sixty-four percent were dominated by female entrepreneurs and practitioners. Liaman (2014) contends that most hotel managers are around 30-39 years old, thus it is a common-sense wisdom that respondents want to work for more years with the same employer. On the contrary, findings conducted by Nanayakkara (2015) in Sri Lanka on human resources particularly women's employment in hotel industry remains very low-less than 8 percent for the leading hotel chains in the country.

Most of the respondents were married (58\%) before employment which implies that most have chosen to have a family of their own but a good number remain single. Thus, most of the respondents finished a college degree (43\%) which also conforms in the findings of Liaman (2014) that that managers running hotels and hostels are bachelor's degree holders and tourism and hospitality managers had bachelor's or master's degree degrees.

Most graduates of hospitality management courses practice their profession in the field as shown in the result of industry-based $(79 \%)$ in terms of position classification. Furthermore, both in the Lodging and Food Services (47\%), belong to the rank and file positions $(57 \%)$, regular or permanent $(89 \%)$, and new in the workplace (58\%). This finding confirms what Celis et al. (2014) discovered in their study that majority of HRM graduates are productively employed and secured a job from one to two years after graduation; that most of the respondents are on contractual arrangement and are working in the Philippines; and majority are professionals working as personnel in HRM establishments. Similar findings, Liaman (2014) asserts that employees with a degree in tourism and hospitality and with the necessary experience are more competent and qualified workers rather than their colleagues with non-hospitality educational background. 
The determination of the level of desired professional competencies, the highest perceived competencies were: Personal Effectiveness Competencies (4.30) and Workplace Competencies (4.23) followed by Industry-Wide Competencies (4.17) and Intellectual Competencies (4.03). This means that the desired professional competencies are indeed priorities by academic institutions in the formation of students and for a successful hospitality industry. The finding confirmed what Wilks and Hemsworth (2011) revealed in their study that hospitality employers tend to see personal qualities and interpersonal competencies as very relevant and most important in the field. In the same way, Jaykumar et al. (2014), found out that hotel managers indicated personality as the most important factor an employee in the hotel industry must possess. Research findings also in agreement with Koenigsfeld's (2011) finding when he revealed that leadership and interpersonal competencies are the most important and most frequently used managerial competencies.

This coincides with the finding of Millar et al. (2008) that educators and professionals are in agreement in terms of competencies in the conceptual domain where critical thinking, analytical, and decision making skills are related with problem solving skills.

Moreover, result in workplace competencies was related to what Nurhazani Mohd Shariff's (2014) finding that tourism and hospitality graduate students must consider major competencies in their preparation before entering the industry such as ability to work in team, ability to inform, learning skills, customer service skill, and ability to support staff, which are considered as important by industry professionals. This finding is supported by Grau et al. (2006) who suggested that all sets of competencies are required for effective management. Further, Silicka (2015) pointed out that the concluded components of the professional competence include professional knowledge obtained during the study process, working attitude, skills and abilities developed during the process of practical activities and social maturity in professional activities such as immersion or internship activities.

In the Specific Industry Sector, the highest proficiencies were the Lodging Management and the Food and Beverage Management (4.22). Meaning that the respondents consider the skills in managing accommodation and skills in managing food and beverage service to be very vital in the industry. Similarly, Resenberg (2004), as cited by Peren (2015) states that in a world progressively based on information technology capacities, coupled with communication competencies for some researchers (Cho 2002), acclaim the most important competencies to be acquired by hospitality students.

Moreover, competencies along Front Office Procedure (4.10); Culinary Arts (4.08); Meetings, Events and Exhibitions Management (4.06); Tour Operations and Travel Management (4.05); Destination Marketing and Management (4.03); Recreation, Amusement and Attractions (3.99); Beverage Service (3.92) were rated high. The result also suggests that all the identified competencies are indeed necessary for practitioners to acquire and develop, while in the industry and more so, for academic institutions, to cultivate such competencies among their students. This confirms the finding of Rutelione (2009) that hotel employees must have well rounded competencies and must be multi - skilled. On the other hand, findings in the studies of Rusette (2000), Johanson (2008), Baum (2006), Wilkins (2006), and Peren (2015), showed that the required competencies identified recognizing customer problems, showing enthusiasm, maintaining professional and ethical standards, cultivating a climate of trust, adapting creatively to change, coping with emotional demands, empathizing with customers, and developing self-management skills.

The results also revealed the correlation between the desired level of professional competencies and the profile of the respondents was significant in the components of Specific Industry Sector Competencies the Beverage Service with the age (0.2132) and civil status (0.2063). It implies that the younger and single respondents in the beverage service were more likely to have higher level of desired professional competencies than the older and married respondents. This finding confirms what Alice Mueni Nzioka (2013) revealed and contended in her study that age and person's marital status influences the way he or she perceives issues. In her study, she found out that perception of the hotel general managers on job related factors varied considerably depending on their age. However, the present finding contradicts what Hagan (2015) revealed in her study that no significant relationship was established between the overall perception of service quality and the age of hotel guests.

On the type of industry sector with the desired level of professional competencies showed a very significant relationship particularly on specific industry sector competencies along Food and Beverage Management (0.2935), Beverage Services (0.2745), Culinary Arts (0.2744). Moreover, it has significant relationship with Personal Effectiveness Competencies (0.2159), Intellectual Competencies (0.2379), Workplace Competencies (0.2059). Furthermore, the same variable is significantly correlated with the specific industry sector competencies along Front Office Procedure (0.2096), Destination Marketing and Management (0.2309), Tour Operations and Travel Management (0.2391). All these could mean further that their level of desired competencies may be dependent on their area of operation whether in the lodging, food and beverage or both. However, those who operate both may have higher expectations than those who are focused on one. This is expected since each industry sector requires skills and competencies specific to that industry sector. This confirms the finding of Kamau and Waudo (2012) that there is a significant relationship between the skills expected by the hospitality industry employers' and the hotels' classification.

Employment status of respondents affects very significant relationship the perceived level of desired professional competencies with specific industry sector competencies along Destination Marketing and Management with a correlation coefficient of 0.3110 and $p$-value of 0.0014; Tour Operations and Travel Management with a correlation coefficient of 0.2562 and a $p$-value of 0.0089; Recreation, Amusement and Attractions with a correlation coefficient of 0.1902 and a $p$-value of 0.0013. Likewise, it has significant relationship with Intellectual Competencies with a 
correlation coefficient of 0.2215 and a $p$-value of 0.0245. It implies that respondents who are regular or permanent are more likely to have higher expectations of the desired professional competencies than those who are on contractual basis.

\section{CONCLUSIONS}

The respondents are in their early adulthood; generally female, married, bachelor's degree holders, industry-based and working in both Lodging and Food Services, holding rank and file positions, regular or permanent, and new in the workplace.

The respondents manifest a very high level of desired professional competencies along Personal Effectiveness Competencies, Workplace Competencies, and Specific Industry Sector Competencies particularly on Lodging Management and Food and Beverage Management.

The respondents also have a high level of desired professional competencies along Intellectual Competencies, Industry Wide Competencies, and Specific Industry Sector Competencies particularly along Beverage Service; Culinary Arts; Front Office Procedure; Destination Marketing and Management; Tour Operations and Travel Management; Recreation, Amusement and Attractions; and Meetings, Events, and Exhibitions Management.

The hospitality professionals and educators' desired professional competencies along age and civil status is significantly correlated with specific industry sector competencies particularly Beverage Service. The type of industry sector is very significantly correlated with specific industry sector competencies particularly Food and Beverage Management, Beverage Service, and Culinary Arts. Same variable is also significantly correlated with Personal Effectiveness Competencies, Intellectual Competencies, Workplace Competencies, and specific industry sector competencies particularly on Front Office Procedure, Destination Marketing and Management, and Tour Operations and Travel Management.

The respondents' level of desired professional competencies along employment status is very significantly correlated with specific industry sector competencies particularly along Destination Marketing and Management; Tour Operations and Travel
Management; Recreation, Amusement and Attractions. It is also significantly correlated with Intellectual Competencies.

Finally, the following desired professional competencies of hospitality professionals and hospitality educators in Nueva Vizcaya: Personal Effectiveness Competencies, Workplace Competencies, Intellectual Competencies and Specific Industry-Sector Competencies particularly on Lodging Management and on Food and Beverage Management, Beverage Service; Culinary Arts; Front Office Procedure; Destination Marketing and Management; Tour Operations and Travel Management; Recreation, Amusement and Attractions; and Meetings, Events, and Exhibitions Management.

\section{RECOMMENDATIONS}

The industry based practitioners and even those in the academe may consider pursuing advanced education to enhance their Intellectual Competencies. They are also encouraged to acquire National Certification qualifications to keep abreast with the latest trends and current best practices.

More opportunities may be provided by administrators for hospitality management educators to attend industry trainings, regular seminars, immersion programs and scholarship grants. This will enable them to communicate openly about research projects and networking. They could also incorporate required competencies into job descriptions to strengthen the over-all learning experience of the students. Some of these desired professional competencies comprise problem solving skills, communication skills, critical thinking skills, team work, and interpersonal skills.

It is highly suggested that balance be made between applied and theoretical approaches, technical competencies and academic curriculum in addition to developing a complex of competencies relevant for service work.

Similar studies be conducted to find out the industry professionals and educators expectations to hospitality graduates comparing various job pairing skills and differences among competencies required in their jobs can be made.

\section{TABLES}

Table 1

Respondents' Level of Desired Professional Competencies

\begin{tabular}{lcl}
\hline Components & $\begin{array}{c}\text { Weighted } \\
\text { Mean }\end{array}$ & Level \\
\hline Personal Effectiveness Competencies & 4.30 & Very High \\
Intellectual Competencies & 4.03 & High \\
Workplace Competencies & 4.23 & Very High \\
Industry Wide Competencies & 4.17 & High \\
Specific Industry Sector Competencies (SISC) along Lodging Management & 4.22 & Very High \\
SISC along Food and Beverage Management & 4.22 & Very High \\
SISC along Beverage Service & 3.92 & High \\
SISC along Culinary Arts & 4.08 & High \\
SISC along Front Office Procedure & 4.10 & High \\
SISC along Destination Marketing and Management & 4.03 & High \\
SISC along Tour Operations and Travel Management & 4.05 & High \\
SISC along Recreation, Amusement and Attractions & 3.99 & High \\
SISC along Meetings, Events and Exhibitions Management $\quad$ Overall Mean & 4.06 & High \\
& 4.11 & High \\
\hline
\end{tabular}


Table 2

Summary of Correlations between the Respondents' Profile in Terms of Age and their Desired Level of Professional Competencies

\begin{tabular}{|c|c|c|c|}
\hline Professional Competencies & $\begin{array}{l}\text { Correlation } \\
\text { Coefficient }\end{array}$ & $p$-Value & Remarks \\
\hline Personal Effectiveness Competencies & 0.0113 & 0.9100 & Not Significant \\
\hline Intellectual Competencies & 0.0217 & 0.8279 & Not Significant \\
\hline Workplace Competencies & 0.0069 & 0.9450 & Not Significant \\
\hline Industry Wide Competencies & 0.0828 & 0.4059 & Not Significant \\
\hline SISC along Lodging Management & 0.0965 & 0.3321 & Not Significant \\
\hline SISC along Culinary Arts & 0.0963 & 0.3330 & Not Significant \\
\hline SISC along Front Office Procedure & 0.1334 & 0.1792 & Not Significant \\
\hline SISC along Destination Marketing and Management & 0.0781 & 0.4327 & Not Significant \\
\hline SISC along Tour Operations and Travel Management & 0.0107 & 0.9144 & Not Significant \\
\hline SISC along Recreation, Amusement and Attractions & 0.1020 & 0.3051 & Not Significant \\
\hline
\end{tabular}

Table 3

Summary of Correlations Between the Respondents' Profile in Terms of Type of Industry Sector and their Level of Desired Professional Competencies

\begin{tabular}{lccl}
\hline Professional Competencies & $\begin{array}{c}\text { Correlation } \\
\text { Coefficient }\end{array}$ & $\boldsymbol{p}$-Value & Remarks \\
\hline Personal Effectiveness Competencies & 0.2159 & 0.0284 & Significant \\
Intellectual Competencies & 0.2379 & 0.0155 & Significant \\
Workplace Competencies & 0.2059 & 0.0369 & Significant \\
Industry Wide Competencies & 0.1829 & 0.0643 & Not Significant \\
SISC along Lodging Management & 0.1733 & 0.0800 & Not Significant \\
SISC along Food and Beverage Management & 0.2935 & 0.0026 & Very Significant \\
SISC along Beverage Service & 0.2745 & 0.0050 & Very Significant \\
SISC along Culinary Arts & 0.2744 & 0.0050 & Very Significant \\
SISC along Front Office Procedure & 0.2096 & 0.0336 & Significant \\
SISC along Destination Marketing and Management & 0.2309 & 0.0189 & Significant \\
SISC along Tour Operations and Travel Management & 0.2391 & $0.0149 \backslash$ & Significant \\
SISC along Recreation, Amusement and Attractions & 0.1301 & 0.1901 & Not Significant \\
SISC along Meetings, Events and Exhibitions Management & 0.1721 & 0.0822 & Not Significant \\
\hline
\end{tabular}

Table 4

Summary of Correlations Between the Respondents' Profile in Terms of Employment Status and their Level of Desired Professional Competencies

\begin{tabular}{lccl}
\hline Professional Competencies & $\begin{array}{c}\text { Correlation } \\
\text { Coefficient }\end{array}$ & $\boldsymbol{p}$-Value & Remarks \\
\hline Personal Effectiveness Competencies & 0.0650 & 0.5139 & Not Significant \\
Intellectual Competencies & 0.2215 & 0.0245 & Significant \\
Workplace Competencies & 0.1113 & 0.2629 & Not Significant \\
Industry Wide Competencies & 0.1131 & 0.2555 & Not Significant \\
SISC along Lodging Management & 0.0989 & 0.3202 & Not Significant \\
SISC along Food and Beverage Management & 0.1368 & 0.1683 & Not Significant \\
SISC along Beverage Service & 0.1019 & 0.3054 & Not Significant \\
SISC along Front Office Procedure & 0.1510 & 0.1278 & Not Significant \\
SISC along Destination Marketing and Management & 0.3110 & 0.0014 & Very Significant \\
SISC along Tour Operations and Travel Management & 0.2562 & 0.0089 & Very Significant \\
SISC along Recreation, Amusement and Attractions & 0.3125 & 0.0013 & Very Significant \\
SISC along Meetings, Events and Exhibitions Management & 0.1902 & 0.0543 & Not Significant \\
\hline
\end{tabular}

\section{REFERENCES}

1. Adeniyi, K. (2011). Knowledge, Skills and Competencies of Hospitality Companies in the South Moravian Region. Retrieved at http://knowledge\%skills\%competencies.article.pdf. on May 2, 2017.

2. Alejandro, N. (2015). Module in Methods of Research. Unpublished Instructional Material, $P W U$.
3. Austra, and Asta, S. (2009). Small Medium Sized Hotel Employee Core Competencies and their Development. Published Dissertation. Spain.

4. Bachelor of Science in Hotel and Restaurant Management in the Philippines.

Retrieved

http://www.finduniversity.ph/majors/bs-in-hoteland-restaurant-management-philippines/ January 28, 2017. 
5. Baum T. (2002). Skills and Training for the Hospitality Sector: A Review of Issues. Published Dissertation. United Kingdom.

6. Best Hospitality Degrees. Retrieved at http://www.besthospitalitydegrees.com/faq/ishospitality-management-still-a-marketable-careerfor-graduates on May 21, 2017.

7. Berezina, K. (2015). The Information Technology (IT) Skills of Hospitality School Graduates as Perceived by Hospitality Professionals. Retrieved at http://www.academicjournals.org on March 2, 2017.

8. Botterill S. \& Tribe, E. (2000). Food and Beverage Management Competencies: Educator, Industry, and Student Perspectives. Hospitality \& Tourism Educator. Published Dissertation.

9. Breen, H., Walo, M., and Dimmock, K. (2006). Assessment of Tourism and Hospitality Competencies: A student perspective. Proceedings of the New Zealand Tourism and Hospitality Research Conference. Published Dissertation, Wellington, Victoria University of Wellington.

10. Brophy, J \& Kiely, $T$ (2002). Competencies: a New Sector. Retrieved at http://journalindustrial.com on October 29, 2016.

11. Brownell, $J \&$ Chung, B (2001). The Management Development Program: A Competency-Based Model for Preparing Hospitality Leaders. Retrieved at http://journalmgmt.edu.com on January 10, 2017.

12. Burns, R. (1972). Behavioral Objectives for Competency-Based Education. Retrieved at http://comp.based.edu. on October 29, 2016.

13. Casado, M. (2006). A Hospitality Management: A Capstone Course. John Wiley \& Sons., Inc. Canada.

14. Castriciones, S. (2013). Influence of Work Ethic and Leadership Style on the Competencies of Entrepreneurs in Bambang: Bases in Conceptualizing Best Practices. Unpublished Dissertation. NVSU

15. Celis, $K \&$ \& Childs, $S$ (2014). Constituting HRM Graduates and Employability after Graduation. Retrieved http://www.mlkrook.org/pdf/cckk_2014.pdf. on May $18,2017$.

16. Cho, S. (2002). Measuring the Impact of Human Resource Management Practices on Hospitality Firms' Performance. Retrieved at http://measuring.impact.humres.article.pdf. on May 3, 2017.

17. Christou, E. (2009). Hospitality Management Education in Greece: An Exploratory Study. Tourism Management, Published Thesis, Greece

18. Chung-Herrera, B.G.Enz, C.A. \& Lankau, M. (2003). "Grooming Future Hospitality Leaders: A Competency Model". Retrieved at http://www.scielo.mec.pt.com on February 8, 2017.

19. Conradie, C. (2012). Student Evaluation of Career Readiness after Completing the Hospitality Management Curriculum at the International Hotel School. Retrieved at http://jointcenter.dc.eco.studies.org on May 2, 2017.

20. DePaulo, B. (20170. More People than ever before are Single-that's a good thing. Published Article. Retrieved at http://www.abc.net.au/news/2017-0426/more-people-than-ever-are-single-and-thats-agood-thing/8473398 on May 2, 2017.

21. Dix, C. (2003). Front Office Operations. Pearson Education. Singapore.

22. Domingo, JG C. (2016). Job Performance and Job Satisfaction of Board
23. Secretaries in State Universities and Colleges in Luzon: Bases for the Formulation of Standard Operational Instruction (SOI) Processes. Unpublished dissertation. NVSU.

24. Dopson, L.R. and Tas, R.F. (2004). A Practical Approach to Curriculum Development: A Case Study. Published Journal.

25. Ennis, M. R. (2008). Competency Models: A Review of the Literature and the Role of the Employment and Training Administration (ETA). Published Dissertation, US Department of Labor. Published Dissertation, US Employment and Training Administration (ETA). United States Department of Labor. Retrieved at www.doleta.gov. on October 29, 2016.

26. Fronda, F. (2015). Tracer Study of Employment of BSHRM Graduates of the La Consolacion University Philippines from 2011-2013. Published Article.

27. Galambos, C. \& Green, R. (2006). A Competency Approach to Curriculum Building: A Social Work Mission. Retrieved at http://journalsocialwork.uk.com on January 10, 2017.

28. Gisslen, W. (2011). Professional Cooking. 7th Edition. New York. John Wiley \& Sons, Inc.

29. Grau, A.S. (2006). Competency Needs among Managers from Spanish Hotels and Restaurants and Their Training Demands. Published Thesis, International Journal Hospitality Management, Spain.

30. Hagan, E. (2015). Service Quality Perceptions \& Socio-Demographic Characteristics of Hotel Guests in the Western Region of Ghana. Journal of Tourism, Hospitality \& Sports vol. 10, 24-26. Retrieved http://service.quality.perception.article.pdf on May 29, 2017.

31. Hauf, J. (1980). Oiling the Wheels of Competence. Retrieved at http://personnelmanagement.org. on May 12, 2017.

32. http://www.acpa.nche.edu/professionalcompetencies

33. http://smallbusiness.chron.com/competencieshospitality-industry-13466.html

34. https://www.okstate.edu/academic.htm

35. Johanson, M. (2010). Revealing Key Competencies of Hospitality Graduates Demanded by Industry: A 25-Year Review. International CHRIE ConferenceReferred Track. Retrieved at http://scholarworks.umass.edu/referred/CHRIE_20 10 on November 30, 2016

36. Jaykumar, V., Fukey, L., and Balasubramanian, K. (2014). Hotel Managers Perspective of Managerial Competency among Graduating students of Hotel Management Program. Published Thesis, India.

37. Kamau, S. W. and Waudo, J (2012). Hospitality Industry Employer's Expectation of Employees' Competences in Nairobi Hotels. Journal of Hospitality Management and Tourism. Department of Hospitality, Kenyatta University, Published Dissertation, Nairobi.

38. Koenigsfeld, J. P. (2012). Revised Competencies for Private Club Managers. International Journal of Contemporary Hospitality Management. Retrieved at http://www.emeraldinsight.com on December 22, 2016.

39. Liaman, A. (2014). Competencies and Qualifications of Staff and Management in Hospitality Establishments. Published Thesis, Prague.

40. Long, N. (2015). Competencies in the Hospitality Industry. Retrieved at 
http://smallbusiness.chron.com/competencieshospitality-industry-13466.html on January 28, 2017.

41. Lowery, L. \& Flohr, J. K. (2005). No Student Left Behind: A Longitudinal

42. Assessment of the Competency Based Framework used to Facilitate Learning in a Capstone Tourism Course. Retrieved at http://journalhospitality\&tourismedu.org. on May 3, 2017.

43. Meal Planning And Preparation Service Resource List. Retrieved at www.nal.usda.gov.fnic/servicelfoodmpl.htm on May 1, 2017.

44. Millar, M. (2008). Hospitality Management Educators Vs. The Industry: A

45. Competency Assessment. Hospitality management. Published Dissertation, University of San Francisco, $U S$

46. Nanayakkara, S. (2015). Women's Participation in Tourism Development in Sri Lanka: An Exploratory Research into Low Levels of Women's Employment in the Hotel Industry. Retrieved at http://www.academia.edu on May 3, 2017.

47. Nzioka, A. (2013). Using Acquisitions to Buy and Hone Core Competencies. Retrieved at http://mergers_and_acquisitions.pdf. on May 3, 2017.

48. Peren, K. D. (2012). Reengineering of Bachelor of Science in Hotel and

Restaurant Management (BSHRM) Curriculum to Harmonize with K to 12 Program: As a Basis for Curriculum Development. Published Thesis, PWU.

49. Professional Competencies. Retrieved at http://www.acpa.edu/professional-competencies on January 28, 2017.

50. Provincial Tourism Office Nueva Vizcaya List of Accredited Hospitality and Tourism Industry PBL Hospitality Management. Retrieved at http://www.fbla-org/hospitality_management.pdf on January 20, 2017.

51. Remolazo, EC (2015). Agritourism Management Practices in Selected Municipalities in the Province of Nueva Vizcaya, Philippines: A Basis for Developing a Comprehensive Agritourism Program. Unpublished Thesis, PWU.

52. Remolazo, EC. (2014). Introduction to Tourism Sectors Manual of Principles of Tourism 1. Unpublished Instructional Material. IFSU

53. Reynolds. M. (2010). Philosophy of the Hospitality Industry Retrieved at http://smallbusiness.chron.com/philosophyhospitality-industry-68606.html on January 28, 2017.

54. Russette, J. (2000). Hospitality Management Competencies-Identifying Mangers' Essential Skills. Cornell Hospitality Quarterly Journal, 41(2), 52-63.

55. Rutelione, A. (2009). Small-Medium Sized Hotel Employees' Core Competencies and their Development. Published Journal. US.

56. Sandwith, P. (1993). A Hierarchy of Management Training Requirements. The Competency Domain Model. Retrieved at http://etd.fcla.edu.pdf on October 12, 2016.

57. Salmorin, M. E. (2007). Methods of Research. Mindshapers Co., Inc: Manila.

58. Scowsill, D. (2015). Travel \& Tourism Economic Impact 2015 World. Retrieved at https://www.wttc.org/- /media/files/reports/economic\%20impact\%20resear ch/regional\%202015/world2015.pdf on January 10, 2017.

59. Shariff, N., Kayat, K, and Abidin, A.L. (2014). Tourism and Hospitality Graduates Competencies: Industry Perception and Expectations in The Malaysian Perspectives. World Applied Science Journal. Published Thesis, College of Business, Sintok, Kedah, Malaysia.

60. Shields P.M. (2014). Handbook of Research Methods. Routledge. Published Handbook. New York.

61. Shin, J. (2014). The Managerial Competencies Required by Indonesia's Leading Hotel Groups A Preliminary Investigation. Published Journal. Retrieved at https://www.researchgate.net on February 2, 2017.

62. Silicka, I. and Lubkina, V. (2015). Theoretical Aspects of the Building Professional Competences of the Hospitality Industry Specialists. Published Thesis, Rezeknes Augstskola, Latvia.

63. Sisson, L.G. (2013). Essential Hospitality Management Competencies: The Importance of Soft Skills. Journal of Hospitality \& Tourism Education. Published Dissertation.

64. Suh, E. and Shanklin, C. (2012). Important Competency Requirements for Managers in the Hospitality Industry. Published Thesis, US.

65. Swanger, $N$ \& Gursoy, D. (2007). An IndustryDriven Model of Hospitality Curriculum for Programs Housed in Accredited Colleges of Business. Published Journal.

66. Tesone, D. and Ricci, P. (2010). Hotel and Restaurant Entry-Level Job Competencies: Comparison of Management and Worker Perceptions. Retrieved at http://www.hospitalityjournals.ucf.com on October 29, 2016.

67. Trehan, R. (2009). Core or Competitive Competence in the Hospitality Industry. Retrieved at www.nationalhotelexchange.com on February 8, 2017.

68. Valachis, L. (2003). Essential Competencies for a Hospitality Management Career: The Role of Hospitality Management Education. Retrieved at https:scholar.hm.competencies.com on January 19, 2017.

69. Weber, K. \& Ladkin, A. (2008). "Career Advancement for Tourism and Hospitality Academics: Retrieved at http://journals.sagepub.com on February 8, 2017.

70. Weinland, J.T. (2013). Taming the Competencies of Timeshare Management: A Competency Domain Cluster Analysis for the Timeshare Industry. PDF. Published Dissertation, Capella University

71. West, J. Core Competencies: An Important Requirements for Managers in the Hospitality Industry. Published Journal. Retrieved at hhtps??www.researchgate.net on April 12, 2017.

72. Wilks, D. and Hemsworth, K. (2011). Soft Skills as Key Competencies in Hospitality Higher Education: Matching Demand and Supply. International English Edition. Published Dissertation, University Portucalense, Department of Management Sciences, Portugal.

73. Wilkinson, R. (2006). Contract Catering: The Skills Required for the Next Millennium. Retrieved at http://internationaljournal.contemporary.com on May 12, 2017.

74. Zabala, V., Encabo, C. and Ramayan, A. (2014). Students Evaluation of the BSHRM Program: Basis for Future Curriculum Revision. Retrieved at http://mindanaostateuniv.edu.ph. on May 14, 2017. 
75. Wang, Y. (2011). Destination Marketing and Management: Theories and Applications. CABI Publication, USA.

US Council on Education for Public Health, 2006.

Competencies and Learning Objectives. Retrieved at www.couneduph.gov. on October 29, 2016.

\section{OTHER REFERENCES}

1. $\left[3^{\text {rd }}\right.$ Grand Ammungan Festival 2011 Souvenir Program.

2. Hospitality News Philippines, (2013).

3. Nueva Vizcaya Provincial Development and Physical Framework Plan 2007- 2013. June 2010.

4. Technical Education Skills and Development Act of 1994: Republic Act No. 7796, Section 22: Establishment and Administration of the National Trade Skills Standards.

5. Technical Education Skills and Development Authority, List of Tech-Voc in Nueva Vizcaya

6. World Travel \& Tourism Council (WTTC), (2014). Global Business.

7. US Department of Education, 2002. 